\title{
THE IMPACT OF POPLAR TREE PLANTATIONS FOR BIOMASS PRODUCTION ON AN AQUIFER WATER BUDGET AND THE BASE FLOW OF A MEDITERRANEAN RIVER BASIN
}

Albert Folch ${ }^{1,2}$ and Núria Ferrer ${ }^{1}$

1) Hydrogeology Group (UPC-CSIC), Department of Geotechnical and Geo-sciences, Universitat Politècnica de Catalunya-BarcelonaTech, Barcelona, Spain e-mail: folch.hydro@gmail.com

2) Institut de Ciència i Tecnologia Ambientals, Universitat Autònoma de Barcelona, Bellaterra, Spain.

\section{Abstract}

Poplar plantations are used for biomass production in many countries. These plantations are often located in areas where the tree roots can reach the water table of shallow aquifers to reduce irrigation costs and increase evapotranspiration, mainly during the summer. This study aims to assess the effects of these plantations on an aquifer water budget and on the stream flow of a Mediterranean basin (Santa Coloma River, $321.3 \mathrm{~km}^{2}$ NE Spain). A numerical flow model was constructed to simulate shallow aquifers and to simulate the stream-aquifer interaction for a period of 9 years. Once the model was calibrated, different land use scenarios, such as deciduous forests, dry farming and irrigated farming, were simulated for comparison. The mass balance shows that poplar extracts an average of $2.40 \mathrm{hm}^{3}$ from the aquifer, i.e., approximately $18 \%$ of the average recharge of the modelled area. This effect reduces the groundwater flow to the main stream and increases the infiltration from the stream to the aquifer. As a result, there is an average reduction in the main stream flow by $46 \%$ during the summer, when the lowest flow occurs and when the river is most sensitive. The results indicate that these impacts should be considered in basin management plans and in evaluating the benefits of this type of biomass production. 
Bioenergy, groundwater-surface water interaction, evapotranspiration, river flow

\section{Introduction}

To survive, humans must use natural resources, such as wood, sustainably in the long-term (Christersson, 2010). In Europe, wood resources, which are considered a prerequisite for building a prosperous society, are becoming scarce. The energy crises between 1973 and 1976 stimulated an intensive search for fast-growing tree species, such as poplars and willows. Poplar (Populus spp.) is well known for its large biomass production, its ability to adapt to different environments, its ability to integrate and synergise with agriculture and its high energy potential (Coaloa and Nervo, 2011). European countries such as Italy, France, Belgium, Spain, Hungary, and Serbia have a long tradition of poplar cultivation. Plantations are usually established on fertile sites, such as riparian areas (Johansson and Karačić, 2011); poplars account for 4\% of the total plantations in Europe.

From an economic perspective, various parts of poplar trees can be used for different types of marketable products. The woody parts can be chipped to produce particle boards, pulp and bioenergy. Additionally, higher quality wood can be used for solid wood products, such as pallets and veneer. During drought, leaves and small branches can be pruned from hybrid poplars to create an inexpensive livestock feed (Fortier et al., 2010). Wood production remains the main objective of growing poplars. In 2008, Spain produced $770.000 \mathrm{~m}^{3}$ of wood from poplar plantations (Coaloa and Nervo, 2011). Furthermore, in many countries, poplar plantations are used for phytoremediation and phytostabilisation of soils contaminated by various pollutants, i.e., boron (Rees et al., 2013), cadmium (Marmiroli et al., 2013), zinc (Van Nevel et al., 2013), lead (Hu et al., 2013), nitrate and phosphate (Merseburger et al., 2011), as well as TCE (Shang and Gordon, 2002). Depending on the treated pollutant, phytoremediation using this type of tree could provide two major services: the rehabilitation and restoration of 
Populus spp. is excellent for the above-mentioned tasks because it grows quickly, providing raw material in relative short periods (Meiresonne et al., 1999). Depending on the desired end product and the local climatic conditions, hybrid poplars can be managed for rotation periods of 2-5 years, 10-15 years and 25-40 years (Johansson and Karačić, 2011). Long rotation periods are used to produce pulpwood and timber, and Short Rotation Coppice (SRC) can produce biomass for energy (Sevigne et al., 2011). Biomass has received attention as a promising way to develop local and sustainable energy sources (Sevigne et al., 2011) that reduce the carbon emission rate (Rowe et al., 2009); thus, biomass is important in many industrial countries. For instance, Sweden obtains $14 \%$ of its energy from biomass, and it has plans to increase bioenergy production and use (Hall and Scrase, 2012). The high content of cellulose in poplars and willows indicates that these trees could also be a potential feedstock for bioethanol production (Rosso et al., 2013). Furthermore, because the poplar tree is a bountiful species in riparian forests, reusing riparian vegetation as biomass for energy production has economic and environmental benefits (Recchia et al., 2010). Although using biomass as an energy source results in a favourable balance between energy use and the environment, the fast-growing poplar trees consume more water than other crops (Petzold et al., 2010). Therefore, the water consumption required by poplars to avoid a $\mathrm{kg}$ of $\mathrm{CO}_{2}$ release is $4.6 \mathrm{~m}^{3}$, and the per unit of energy obtained is $45 \mathrm{~m}^{3} \mathrm{GJ}^{-1}$ (Sevigne et al., 2011).

Because of their high water consumption, poplar plantations have important water needs. For this reason, many poplar plantations are located in areas with a shallow groundwater table (Allen et al., 1999; Guidi et al., 2008; Meiresonne et al., 1999; Petzold et al., 2010; Pistocchi, 2009; Wilske et al., 2009; Zhang et al., 1999). After one year of growth, during all rotation periods, poplars can obtain water directly from the aquifer (Fu et al., 2013; Quinn et al., 2001; Wilske et al., 2009). This phenomenon produces direct groundwater evapotranspiration, increases the discharge from the aquifer, and modifies the hydrological cycle in areas where these plantations are located. This practice is common in arid and semiarid areas (Loheide et al., 2005; Pistocchi, 2009; Wilske et al., 2009), such as in Mediterranean countries, because the 
irrigation-related growing costs are significantly reduced. Nevertheless, many shallow aquifers are located in alluvial planes where important river-aquifer interactions occur (Krause et al., 2007; Langhoff et al., 2006; Mas-Pla et al., 2012; Parkin et al., 2007); the groundwater discharge to these rivers helps maintain the environmental water flow (Krause et al., 2007; Markovic et al., 2013; Parkin et al., 2007). The increase in aquifer evapotranspiration, i.e., aquifer discharge, due to poplar plantations could have the same effect as groundwater pumping, whose impact in river base flows and related ecosystems has already been demonstrated (Wilske et al., 2009; Yin-Phan et al., 2014; Zhang et al., 1999).

Following the Water Framework Directive (WFD) (200/60/CE), it is important to study the potential effect of poplar plantations on rivers basins to define an appropriate regulation of pressure and impacts imposed by the various water users; the aim would be to maintain the healthy ecological status of river basins. Although some papers explore the link between Populus spp. biomass production and water consumption (Rowe et al., 2009; Sevigne et al., 2011) or its environmental impact (Rowe et al., 2009), the impact of poplar plantations on river base flows is not as well known. Thus, in this paper, we characterise and quantify the impact Populus plantations on the aquifer water balance and the base flow of a Mediterranean stream by means of numerical modelling. As a paradigmatic example, a numerical flow model considering groundwater and river/aquifer interaction was constructed to simulate the Santa Coloma basin (Catalonia, NE Spain), where $3 \%$ of the land cover is poplar plantations, $27 \%$ of which are located near the main stream.

\section{Study site}

The Santa Coloma basin is located in NE Catalonia (NE Spain) in the range-and-basin area of La Selva. Santa Coloma de Farners is the most significant village, with more than 12,600 habitants. The other towns within the study area are Sils, Riudarenes and Caldes de Malavella, with a total population of 12,717 . This zone is characterised by intense agriculture and farming activities, along with a growing industrial sector and urban development. Additionally, poplar 
trees are used for paper production and the energy industry. This area has a Mediterranean climate characterised by an annual rainfall between 700 and $900 \mathrm{~mm}$ and an average temperature between 12.8 and $29.3^{\circ} \mathrm{C}$ during the study period. The river basin area is $321.3 \mathrm{~km}^{2}$, with a total length of $21 \mathrm{~km}$. Low stream flow occurs during summer, with almost no flow at some locations during the driest years.

Geologically, the range area is formed by igneous and metamorphic hard rocks, while the basin Neogene sedimentary infilling is constituted by alternating silts, arkosic sands, gravels and conglomerates with low clay content (Fig. 2). The Selva basin has been hydrogeologically characterised in detail in previous studies (Folch and Mas-Pla, 2008; Folch et al., 2011; Folch, 2011; Menció et al., 2010; Puig et al., 2013). In the Santa Coloma basin area, groundwater is stored under unconfined conditions in deep sedimentary formations. A multi-layered aquifer system under confined or leaky conditions can reach a total thickness of more than $200 \mathrm{~m}$. The shallow aquifer is formed by the surface Neogene sedimentary materials and the alluvial quaternary deposits associated with the drainage network. The most important alluvial formation in the area is related to the main Santa Coloma stream from Santa Coloma de Farners to Riudarenes, with a maximum thickness between 15 and 20 metres (Figs. 1 and 2). Apart from river-aquifer interactions, the groundwater flow in the sedimentary formations is also influenced by upward flows along the main regional faults (Folch et al., 2010; Folch and Mas-Pla, 2008; Folch et al., 2011; Folch, 2011; Menció et al., 2010).

\section{Methodology}

\subsection{Aquifer evapotranspiration by poplar trees}

Evapotranspiration (ET) is an important factor in the water and energy balance, particularly in zones with shallow groundwater, plantations and riparian areas, where poplar trees are common. Evapotranspiration in riparian forests can be a major component of the annual water budget in arid and semiarid catchments. For example, the ET in the forested extent of the riparian vegetation along the Middle Rio Grande in New Mexico represents $20-30 \%$ of the total 
estimated water depletion of this river reach (Dahm et al., 2002). However, there are few studies that directly quantify ET from the aquifer (water table) in Mediterranean areas.

136

It is difficult to quantify the direct ET from groundwater due its temporal and spatial variability. To calculate this parameter, several methods have been used with disparate results. Groundwater evapotranspiration can be estimated using daily fluctuations of the groundwater level, well hydrographs or streams records. These methods are cheaper than monitoring ET with lysimeters (Yin et al., 2013). Three common mathematical equations can be used to calculate ET from an aquifer. The most traditional equation is the White method (White, 1932), which has been improved over the years to yield the Hays (2003) (Hays, 2003) and Loheide methods (Loheide et al., 2005). These three methods rely on different algorithms and different data sources to calculate the variable groundwater flow; thus, they produce different ET rates, as shown by Yin et al. (2013).

Using direct field measurements, such as lysimeters, to calculate the ET rate provides values that are frequently not regionally representative (Guidi et al., 2008; Pistocchi, 2009). Another common field method to quantify aquifer evapotranspiration (Dahm et al., 2002; Steinwand and Harrington, 2006; Wilske et al., 2009) is the eddy covariance technique, in which the vertical air movement characterises the energy fluxes above the canopy; the calculation is converted to a rate of ET expressed as a quantity per unit of time. However, this method requires expensive equipment and only provides a local estimate of evapotranspiration. ET can also be calculated by sap flow rates that are strongly related to transpiration; the aquifer transpiration by an individual tree can be estimated and scaled to the stand level (Allen et al., 1999; Boronina et al., 2005; Meiresonne et al., 1999; Petzold et al., 2010; Zhang et al., 1999). Additionally, ET can be simulated by water balance modelling. This type of method consists of different modules where the one-dimensional water transport in the soil is described and the actual transpiration is the integral of the root water uptake over the profile soil. As with all models, the input data are from a meteorological station, and soil hydraulic properties and other field parameters are required (Meiresonne et al., 1999). 
Although there are several methods for calculating ET from an aquifer, the ET results and the

162

163

164

165

166

167

168

169

170

171

172

173 scale at which they are estimated vary. Furthermore, most of these estimation techniques are applied to establish the groundwater evapotranspiration rate in riparian areas (Ajami et al., 2012; Boronina et al., 2005; Butturini et al., 2002; Chen, 2007; Pistocchi, 2009; Tabacchi et al., 2000; Yin et al., 2013; Yin-Phan et al., 2014), and only a few studies focus on the evapotranspiration from poplar or willow plantations.

One study compares two methods (sap flow and WAVE water balance modelling) for a poplar plantation in Flanders (Belgium) and finds similar results (Meiresonne et al., 1999). This work was conducted in an area with similar conditions to those found in the SCR basin: the climate conditions (annual precipitation of approximately $750 \mathrm{~mm}$ and an average temperature of $9^{\circ} \mathrm{C}$ ), type of trees (Populus spp.), average tree age (average 15 years in both cases), tree spacing ( $7 \mathrm{x}$ $7.5 \mathrm{~m})$, type of soil and shallow water table $(<5 \mathrm{~m})$. Although the average temperatures in summer and throughout the year are lower in Flanders (maximum of $21.6^{\circ} \mathrm{C}$, minimum of $12.8^{\circ} \mathrm{C}$ ) and are not equally distributed compared with our study area (maximum of $29.3^{\circ} \mathrm{C}$, minimum of $13.5^{\circ} \mathrm{C}$ ), the ET values found in this study provide a minimum estimate of the expected ET we could find in the Santa Coloma basin.

The study by Meiresonne et al. (1999) quantified the transpiration of a fast-growing 13-year-old monoclonal poplar during summer when direct ET from groundwater occurs. The study period was from August to September with a total poplar transpiration of $320 \mathrm{~mm}$; the average minimum value was $2 \mathrm{~mm} /$ day, and the average maximum value was $4 \mathrm{~mm} /$ day. The days with maximum ET coincided with days with no precipitation, while the low ET rates were associated with rain events. These results are comparable with the study of Zhan et al. (1999) for different climatic conditions and younger trees, where the maximum ET was $3.6 \mathrm{~mm} /$ day and the minimum was $2.7 \mathrm{~mm} /$ day. These ET values were obtained by sap flow, leaf area, environmental condition and stomatal conductance measurements in the study area. In our work, the ET from the aquifer was estimated based on the rain events from June to September. 
During other months of the study period, the direct ET from the aquifer is negligible, but the total ET is non-negligible.

189 The aquifer ET values of the above-mentioned study are in the range of the groundwater evapotranspiration found in riparian forests with the same climatic conditions in the Furiosos stream, which is 20 kilometres away from the modelled area (Sabater and Bernal, 2011). Although riparian forests, unlike poplar plantations, are natural ecosystems, poplars are still abundant. Sabater and Bernal (2011) showed that the actual evapotranspiration from riparian forests during the vegetative period (April-October) is between 2 and $5 \mathrm{~mm} /$ day.

\subsection{Modelling approach}

The presented model is based on a previous model from the Catalan Water Agency (ACA, November 2009). The goal is to define an appropriate mass balance to assess the available water resources for enforcing the WFD. The finite difference numerical model Modflow (McDonal and Harbaugh, 1988) and the graphical interface Visual Modflow Pro 4.3 were used.

The model integrated the shallow Neogene materials, the alluvial formations, and the related river/drain systems (Fig. 2). Granitic rocks of the Guilleries range area and the effect of upward vertical flow from regional faults were included in the model as boundary conditions (Fig. 3).

The initial modelling approach is explained in Folch et al. (2010) for the period of 2003-2009. In summary, this model is constituted by a finite difference grid with four horizontal layers, each with a constant thickness of $10 \mathrm{~m}$ and 48.408 active cells. A major refinement was conducted along the main alluvial formations with cell widths between 40 and $120 \mathrm{~m}$. Distinct types of boundary conditions are used (Fig. 3). Constant flow cells are located in the upper reaches of the alluvial formations to represent the groundwater flow from the upper part of the reaches not included in the model domain. A general head boundary is intended to represent the contribution of the fault zones to the nearby alluvial formation, as well as the fluxes from the weathered granite. Constant head is defined at the lower reach of the alluvial formation. A river boundary condition is applied to the SCR main stream, while drainage boundary conditions are 
selected for all natural and ancient man-made drains located along the basin in which water only

214 flows during periods of rain. A no-flow boundary is defined for the Neogene materials in the northern hydrographic limit of the SCR basin (Fig. 2).

216 The recharge rate was estimated independently based on the soil mass balance by considering

217 several parameters, such as land use based on a land cover map of Catalonia (2005-2007) (for

218 interpretation of the references in this map, the reader is referred to the web version of this

219 figure), retention capacity, wilting point, soil depth, field capacity and the runoff threshold among others. Groundwater exploitation by different water users has also been included by considering agriculture, cattle stock, industrial extraction and water supply. To simulate returns from waste water treatment plants, injection wells were included in the cell near the stream (modelled as a river and/or a drain) where the facility was located. Irrigation returns were also included in the soil mass balance using the GARCO 1.0 program of the Catalan Water Agency. Finally, hydraulic parameters were obtained from previous studies and were adjusted through calibration processes; a final set of 20 hydraulic conductivity zones was obtained (Fig. 4).

The model used for this exercise is an updated version with improved hydrogeological features compared with the previous model:

1) A better characterisation of the groundwater flow from the granite formations based on hydrochemical, piezometric and stream flow data (ACA, October 2010a). Thus, a new general head boundary condition has been included in the model domain (GHB2, Fig. $3)$.

2) An improved definition of hydraulic conductivity and storage coefficient values of the alluvial formation related to the Santa Coloma main stream based on a long-term pumping test (ACA, December 2010b).

3) Direct groundwater evapotranspiration produced by poplar plantations has also been included as extraction wells in the model. Thus, pumping wells have been added in those cells to represent areas with poplar plantations. In each cell, a pumping rate equivalent to the groundwater evapotranspirated by the trees within the cell area has been assigned. Poplar plantations are considered twice in the basin water balance: 1) in 
the soil water balance to define the infiltration rate and 2) as extraction wells to simulate the direct evapotranspiration from the aquifer during summer (Fig. 5).

All new features included in the simulation provide a modelling result that is more indicative of the observed values, with a more realistic water budget of the Santa Coloma basin. Furthermore, additional years are included: 9 years under transient conditions between 2003 and 2011, with a significant range in precipitation (between 366 and $410 \mathrm{~mm}$ per year). For calibration, between 2 and 100 observation wells from several field campaigns (February, July and December 2003; May and October 2004; February, May and October 2005; May 2006 December 2008, May 2009, September 2009, April 2010) and one monthly monitoring point for the main alluvial formation were used. The initial hydraulic heads were defined according to the result of a previous steady-state simulation, which included all terms affecting the water balance.

Once the model was calibrated, it was run for different land uses to study the effects of poplars on the base stream flow and on the basin water balance. Three distinct plantations were simulated with the following land cover types: 1) deciduous forest, 2) dry farming and 3) irrigated crops.

\section{Results and discussion}

\subsection{Numerical flow model}

\subsubsection{Calibration and fitting}

After including the new hydrological and hydrogeological information in the initial model (Folch et al. 2010), a posterior model calibration was conducted. During this process, different conductivity zones were formed based on the geological formations (Fig. 4) in Table 1. In the cells that represent two geological formations, an intermediate hydraulic conductivity between the formations was assigned. In the Santa Coloma alluvial formation, two terraces were differentiated according to ACA (2010b) to define the essential river-aquifer interaction. The first terrace (closest to the stream) has a K value of $175 \mathrm{~m} /$ day, and the more distant terrace has 
a value of $90 \mathrm{~m} /$ day (ACA, December 2010b). Similarly, the specific storage $\left(\mathrm{S}_{\mathrm{s}}\right)$ is $0.01 \mathrm{~m}^{-1}$ for

267 the terrace closest to the stream and $0.001 \mathrm{~m}^{-1}$ for the terrace farthest from the stream.

268 The transient simulation reproduces the temporal evolution of natural and human influences on

269 the hydrogeological system and estimates the flow exchange between the stream and the

270 aquifer. Simulated and observed heads must be compared to demonstrate the goodness-of-fit of

271 the model. The results show that approximately $70 \%$ of the simulated head data for May 2009 ,

272 the campaign with many observation wells, exhibits a good correlation with the observations (R

273 of 0.98 and a standard error of the estimate of $\pm 0.41 \mathrm{~m}$ ). The maximum difference between the

274 observed and simulated heads is $14.5 \mathrm{~m}$, and the minimum difference is $0.009 \mathrm{~m}$, with an 275 average of $0.34 \pm 0.41 \mathrm{~m}$ for the entire modelled domain (Fig. 7). The largest discrepancies are 276 found in the Neogene sedimentary formations due to the multi-layered character of the aquifer 277 (Folch et al., 2010).

278 In the main alluvial formation, following the main stream, the correlation coefficient (R) 279 between the simulated and observed head is 0.99 . The difference between the observed and simulated heads is lower than the entire modelled domain $(0.3 \pm 0.36 \mathrm{~m})$. The observed (Fig. 8) were available during 2003-2007. The maximum difference between the observed and simulated hydraulic head during the summer is less than $0.4 \mathrm{~m}$. However, annually, the best fit occurred for the 2007-2011 period. This improvement between the observed and modelled data is attributed to the hydrogeomorphological changes observed in the main stream. A change has occurred in the river morphology, from a braided (high flow and high sediment supply) to a single-thread channel (flow predominance) (Fig. 6). This observed change could induce flushing of fine material in the main channel to increase the hydraulic conductivity (Nowinski et al., 2011), i.e., increasing the river conductance.

Although this geomorphological change could be produced by different factors (land use change, climatology, etc.), it is mainly attributed to the construction of a motorway in the 
headwaters of the main stream in 1998, as shown by Batalla and Sala (1996) in a nearby stream.

293 Because no data are available, a single value for the river conductance was used for the

294

295

296

297

298

299

300

301

302

303

304

305

306

307

308

309

310

311

312

313

314

315

316

calibration; the value had the best fit after 2007 during the driest years (Fig. 8).

The model improved the fit between the observed and simulated heads in the main alluvial formation compared with the initial version presented in Folch et al. (2010). Although new hydrogeological features are considered in this updated version, the improved modelling results are mainly attributed to the consideration of direct groundwater ET of poplar plantations, which represents $27 \%$ of the land use in this area (Fig. 1). Therefore, the results that include aquifer water extraction by poplars are superior.

The model also shows a good correlation with the total stream discharge during the low-flow periods (summer) (Fig. 9), when the stream flow is mainly controlled by groundwater discharge, as observed at the basin gauge station downstream of the modelled area (Fig. 2). Groundwater discharged in the stream network was calculated by summing the groundwater discharge along the drains (Drain) and the main stream (Stream gain) and by diminishing the stream water infiltrating the aquifer (Stream loss) (Table 2). The rise and fall of the Santa Coloma river flow show that in some months, the main stream is nearly dry due to the low-flow of the summer. Because of the lack of quality data, the period of comparison is only 2003 to 2007 , despite the improved adjustment with the observed head in the wells after 2008.

\subsubsection{Water Budget}

The main water inputs to the system are rainfall recharge, groundwater flow from the granite formations (General head boundary in Modflow terminology), water from the upper reaches not drawn in the simulated area (represented as constant flux in the model), returns from waste water treatment plants that are represented as injection wells (Wells in) and stream contributions from the main stream during water loss (River leakage in). The outputs of the system are the groundwater discharge to the adjacent river basin (constant head), the exploitation via wells 
(GW extraction) and the outflow from the aquifer to the drains (Drains out) and to the main stream when losses occur (River leakage out) (Table 2).

319 The largest input in the water balance is recharge. With an average value of $13.2 \mathrm{hm}^{3}$ over the modelled period, recharge represents $60 \%$ of the total input in the aquifer. This value changes over the study period because it depends on climate variations. The dry years (e.g., 2007) the recharge is up to $88 \%$ lower than that in the wet years (2003 and 2011).

323

Groundwater from granite formations provides a total volume of $1.43 \mathrm{hm}^{3}$ every year, which is approximately $7 \%$ of the total inputs of the system. This input flow represents a significant percentage $(60 \%)$ of the direct evapotranspiration of the poplar plantations located in the alluvial aquifer near this tectonic contact. Therefore, the flow of the fault zone is an important element that plays a significant role in the water balance. The returns from waste water treatment plants represent an average of $4.42 \mathrm{hm}^{3}$. This term also varies with the recharge term because the treated waste water is lower during drought periods than during other years.

The main outputs of the system are produced by extraction via pumping wells, drains and poplar plantations. Approximately $20 \%$ of the output is from exploitation wells for agriculture, industry and domestic water supplies $\left(4.10 \mathrm{hm}^{3}\right)$. Furthermore, the drains are responsible for a significant loss of groundwater resources $\left(9.3 \mathrm{hm}^{3}\right)$, approximately $70 \%$ of the total recharge. This percentage represents the effective action of such historical drains on wetlands, except in summer when the loss of groundwater is zero because the recharge is small and the water table is low. Groundwater transpiration produced by poplar plantations $\left(4.10 \mathrm{hm}^{3}\right)$ represents approximately $12 \%$ of the total output of the system and $18 \%$ of the total rainfall recharge of the modelled period. Groundwater transpiration is an important term to consider in the water budget as it is relatively constant over time compared with the variability in the recharge term.

Therefore, changes in the water storage in the aquifer (In-Out, Table 2) supply the amount of water needed for the plantations in the driest years (low recharge), as seen in 2006, 2007 and 2009. The aquifer works as a buffer to reduce the impacts of these types of plantations on the 
overall components of the water budget, specifically on the stream flow during the driest months. However, this buffer capacity can be considerably lower if the dry period lasts more than one year because the water table level would be lower and less groundwater discharge would reach the streams.

The flow exchange between the main stream course and the alluvial aquifer is not constant over the year or along the stream because the stream flow is subject to various influences, such as treated waste water in tributaries, well extraction and transpiration from poplar plantations. Thus, the main stream can undergo a simultaneous gain and loss. This dual behaviour is shown in the potentiometric map from the numerical flow model: the upper part of the river tends to gain water, while the middle of the river tends to lose water. The dual "gaining/losing" characteristic of the stream influences the stream base flow by reducing it when losses occur and by increasing it when gains occur (Fig. 10).

There is also an intra-annual variation in the relation between the stream and the aquifer. During summer, the aquifer flow contributions to the river are reduced in the stretch of stream gaining water, while the infiltration from the stream to the aquifer increases in stream section losing water. An important reduction in the stream base flow is observed during this period (Fig. 10). This dual dynamic water flux between the aquifer and the stream has been observed in Mediterranean riparian zones where the riparian vegetation induces infiltration from the river to the aquifer and reduces the flow from the aquifer to the river (Medici et al., 2008; Mencio et al., 2014).

Lastly, geomorphological changes in the main stream and resulting change in the stream-aquifer interaction are observed. After 2007, stream loss tends to increase simultaneously with a decrease in the groundwater discharged to the main stream (stream gain) (Table 2). It is difficult to quantify the observed change due to the complexities of the aquifer water balance because it depends on the yearly inputs and outputs of the system and on the changes in storage related to the previous year's water budget. However, regarding the monthly gain and loss behaviour (Fig. 
10), the main difference is not observed in summer. Nevertheless, this behaviour affects the

370 water budget of the aquifer system.

371 balance and related river-aquifer interaction

373

Once the model was calibrated, to compare the effects of poplars with other land uses, the area

As mentioned, the results shown in Table 3 suggest that the water stored in the aquifer acts as a occupied by poplar plantations was simulated with other land cover: deciduous forest, dry farming and irrigated farming. Consequently, the infiltration rate changed according to the soil balance with the new land cover. Groundwater extraction (direct evapotranspiration) for those areas occupied by poplars was modified and adapted to these new scenarios. In the case of irrigated farming, groundwater extraction was simulated according to the pumping rates in the irrigation areas of the basin; groundwater extraction was removed for deciduous forest and dry farming.

As mentioned, the effect of direct groundwater evapotranspiration by poplar plantations corresponds to approximately $18 \%$ of the average recharge. Although it depends on precipitation (Meiresonne et al., 1999) over the entire modelled period, the direct poplar ET is between 2.31 and $2.52 \mathrm{hm}^{3} /$ year, even with important changes in precipitation/recharge (2007 vs. 2003). In this sense, for the driest years (e.g., 2007), the direct evapotranspiration from the aquifer was almost equal to the aquifer recharge. Poplars affect the entire mass balance and thus influence the relation between the main stream and the main inputs and outputs from the aquifer (Table 3). The main influence of the three plantation types is manifested in the stream flow by reducing the discharge of the aquifer into the drains (Drain) and into the main stream (stream gain) and by increasing the infiltration of the stream water to the aquifer (stream loss). All these changes produce an annual 1.03 to $2.09 \mathrm{hm}^{3} /$ year decrease in the groundwater discharged in the basin streams/drains compared with the deciduous forest (Table 3). buffer capacity. However, when the lowest recharge occurs (2007 and 2009, Table 2), the buffer 
capacity will also decrease. This phenomenon is observed in the years with the lowest recharge and/or dry summers (2007 and 2009, Table 2), in which the impact of poplar plantations is prolonged compared with the deciduous forest (see gain and/or loss behaviour evolution in Figure 11). In 2007, the flow reduction occurs from May 2007 to January 2008; in 2009, the impact is prolonged 8 months, from June 2009 to January 2010 (Fig. 11). Therefore, when dry years occur consecutive, this buffer capacity is progressively reduced. In contrast, in the years with high recharges, the groundwater recharge to the river is recovered at the end of summer, allowing the aquifer to act as a buffer the following year.

The precipitation pattern observed over dry summers and/or over long periods with low precipitation is similar to the future patterns expected in the Mediterranean, as shown in other studies (Founda and Giannakopoulos, 2009; Mas-Pla et al., 2012; Pal et al., 2004). Therefore, the impact of poplar plantations on the aquifer and on the stream base flow is expected to increase in future decades. Aquifer properties play an important role in determining which geological formations with a high porosity/storage capacity in shallow aquifers will have high buffer capacities.

To understand the effects of poplar plantations, the stream-aquifer interaction (i.e., the gain and loss behaviour) was studied in more detail in the Santa Coloma main stream. This area is the best characterised by the model (ACA, December 2010b; ACA, October 2010a), and it contains the highest density of poplar plantations, i.e., $27 \%$ of the main alluvial aquifer surface linked with the main stream is occupied by poplar plantations (Fig. 1).

Then, to compare the total effect of poplar plantations on the stream base flow, considering the changes produced in the stretches with water gain and loss, with other scenarios with different land uses, we apply the following equation:

$$
\% \text { Total Effect }=\left(\left(\frac{S G_{\text {poplar }}-S G_{\text {scenario }}}{S G_{\text {poplar }}}\right)-\left(\frac{S L_{\text {poplar }}-S L_{\text {scenario }}}{S L_{\text {poplar }}}\right)\right) * 100
$$


where the total effect is the reduction or increase (percentage) in the main stream flow due to

420 different scenarios compared with poplar plantations; $S G_{p o p l a r}$ (Stream gain) is the flow to the 421 aquifer in the scenario with poplar plantations ( $\left.\mathrm{hm}^{3} / \mathrm{month}\right) ; S G_{\text {scenario }}$ is the same flow but with 422 the results of the model with another scenario (deciduous forest, irrigation or dry crops) $423\left(\mathrm{hm}^{3} / \mathrm{month}\right) ; S L_{\text {poplar }}$ (Stream loss) is the infiltration of the main stream to the aquifer with 424 poplar; and $S L_{\text {scenario }}$ represents the same flow but with the results of the other scenarios mentioned ( $\mathrm{hm}^{3} /$ month).

During the summer (June-September), when the stream flow is controlled by stream-aquifer 427 interactions, a $46 \%$ reduced stream flow is observed compared with a deciduous forest scenario; this values reaches $55 \%$ in the driest years. For the same months, the minimum reduction of the flow is approximately $33 \%$ in 2004 . In the case of dry crops, the main stream flow annually increases an average of $33 \%$ (maximum of $42 \%$ ). These differences indicate that the areas that are currently inhabited by poplar plantations would be occupied by deciduous forests or dry crops, and there would be an increase of at least $30 \%$ in the stream flow during the summer (Fig. 11).

434

Annually, the scenario with irrigated crops is more damaging than the current situation with poplars, with an average annual groundwater flow reduction of $0.01 \mathrm{hm}^{3}$ to the river. However, during summer months (June-September), irrigated crops would reduce the stream flow by 5\% more, on average, than poplar plantations (Fig. 12) because groundwater extracted for agriculture occurs from spring until the end of August, whereas plantations mainly extract water from June to September. Furthermore, during spring, the main stream is greatly influenced by surface runoff, limiting the impact of these extractions.

\footnotetext{
442 The impact of poplar plantations on an aquifer water budget and on the stream base flow of the 443 Santa Coloma basin was quantified by means of a numerical flow model. Poplar plantations 444 account for $30 \%$ of the aquifer withdrawal and approximately $18 \%$ of the total aquifer recharge.
} 
Furthermore, because direct groundwater evapotranspiration mainly occurs during summer

446 (June to September), when the stream flow is lowest, there is a flow reduction of $46 \%$ compared

447 with a natural forest. Thus, poplar tree plantations significantly modify the natural flow conditions of Mediterranean streams during the months with the lowest flow.

449

During dry years, water stored in the aquifer acts as a buffer by limiting the effect of the poplars on the stream flow. However, under multi-year droughts, a more critical impact is expected.

451 Furthermore, despite the presented case, geomorphological changes observed in the main stream 452 do not appear to have an important influence on the flow. The presented result show that the 453 impact of poplar plantations on the aquifer water balance and on the stream flow should be

467 In contrast to the direct groundwater extraction by poplar plantations, wells used for irrigation considered in conjunction with other variables that affect the system (e.g., surface and groundwater extraction and other land use changes).

Comparing poplar plantations with other land uses, the least influential scenario is dry farming or a deciduous forest. Furthermore, the scenario with irrigated farming would be similar to that with poplar plantations because the Santa Coloma stream flow would decrease by a similar volume during the summer. However, in the scenarios with irrigated farming, the river flow is also impacted at the end of spring when the input of surface water to the river system is high.

Nevertheless, the impacts of these plantations on river/streams and related ecosystems should not be considered equivalent to the effects of riparian forests in the same hydrogeological settings. Although both land uses produce an increase in evapotranspiration-regulating nutrients and/or filtrating pollutants (Butturini et al., 2003; Flewelling et al., 2014; Hanson et al., 1994; Sabater et al., 2003), riparian forests also promote habitat diversity and sediment retention, among others ecosystem services (García-Arias et al., 2014). are controlled by water agencies. The owners of these wells pay a specific rate for water consumption. Thus, water withdrawal produced by poplar plantations is not controlled or included in basin water management plans. Because of their impact on the water budget and on 
471 the river base flow during the summer, legislation should be reviewed to include these types of

472 plantations in basin water management plans; further, these plantations may even be considered

473 water users by local/national water agencies.

474 Additional research is needed to conceptualise the costs and benefits of this type of non-natural

475 plantation for biomass production, specifically, the associated economic benefits and the effects

476 on the water budget (i.e., stream flow) at various scales (local, basin or national level).

477

478

\section{Acknowledgements}

479 This study has been financed by the Spanish Government with the projects CGL2011-29975-

480 C04-04 and SCARCE (Consolider-Ingenio 2010, CSD2009-00065) and the Catalan Water

481 Agency and the Postdoc Grants 2013 of the Spanish Ministry of Economy and Competitiviness.

482

Appendix A. Supplementary data

Supplementary - data

485

http://www.creaf.uab.es/eng/index.htm.2014.11.01.

486

\section{References}

488

ACA. Characterization of the hydraulic parameters of the Pliocuaternay aquifer of the Santa

Ajami H, Maddock T, III, Meixner T, Hogan JF, Guertin DP. RIPGIS-NET: A GIS Tool for 
Allen SJ, Hall RL, Rosier PTW. Transpiration by two poplar varieties grown as coppice for biomass production. Tree Physiology 1999; 19: 493-501.

Boronina A, Golubev S, Balderer W. Estimation of actual evapotranspiration from an alluvial aquifer of the Kouris catchment (Cyprus) using continuous streamflow records. Hydrological Processes 2005; 19: 4055-4068.

Butturini A, Bernal S, Nin E, Hellin C, Rivero L, Sabater S, et al. Influences of the stream groundwater hydrology on nitrate concentration in unsaturated riparian area bounded by an intermittent Mediterranean stream. Water Resources Research 2003; 39.

Butturini A, Bernal S, Sabater S, Sabater F. The influence of riparian-hyporheic zone on the hydrological responses in an intermittent stream. Hydrology and Earth System Sciences 2002; 6: 515-525.

Chen X. Hydrologic connections of a stream-aquifer-vegetation zone in south-central Platte River valley, Nebraska. Journal of Hydrology 2007; 333: 554-568.

Christersson L. Wood production potential in poplar plantations in Sweden. Biomass and Bioenergy 2010; 34: 1289-1299.

Ciadamidaro L, Madejon E, Puschenreiter M, Madejon P. Growth of Populus alba and its influence on soil trace element availability. Science of the Total Environment 2013; 454: $337-347$

Coaloa D, Nervo G. Poplar wood production in Europe on account of market criticalities and agricultural, forestry and energy policy, Actas del Tercer Congreso Internacional de las Salicáceas en Argentina 'Los álamos y los sauces junto al paisaje y el desarrollo productivo de la Patagonia' Neuquen, Argentina 16-19 Marzo 2011., 2011, pp. 9.

Dahm CN, Cleverly JR, Coonrod JEA, Thibault JR, McDonnell DE, Gilroy DF. Evapotranspiration at the land/water interface in a semi-arid drainage basin. Freshwater Biology 2002; 47: 831-843.

Flewelling SA, Hornberger GM, Herman JS, Mills AL, Robertson WM. Diel patterns in coastalstream nitrate concentrations linked to evapotranspiration in the riparian zone of a lowrelief, agricultural catchment. Hydrological Processes 2014; 28: 2150-2158. 
Folch A, Casadella L, Astui O, Mencio A, Massana J, Vidal-Gavilan G, et al. Verifying conceptual flow models in a river-connected alluvial aquifer for management purposes using numerical modeling. Proceedings of the Xviii International Conference on Computational Methods in Water Resources (Cmwr 2010) 2010: 730-737.

Folch A, Mas-Pla J. Hydrogeological interactions between fault zones and alluvial aquifers in regional flow systems. Hydrological Processes 2008; 22: 3476-3487.

Folch A, Menció A, Puig R, Soler A, Mas-Pla J. Groundwater development effects on different scale hydrogeological systems using head, hydrochemical and isotopic data and implications for water resources management: The Selva basin (NE Spain). Journal of Hydrology 2011; 403: 83-102.

Fortier J, Gagnon D, Truax B, Lambert F. Biomass and volume yield after 6 years in multiclonal hybrid poplar riparian buffer strips. Biomass and Bioenergy 2010; 34: $1028-1040$.

Founda D, Giannakopoulos C. The exceptionally hot summer of 2007 in Athens, Greece - A typical summer in the future climate? Global and Planetary Change 2009; 67: 227-236.

Fu JP, Lan ZP, Sun SW, Liu JQ, Zhang Y. A study on distribution of root system of populus $\times$ euramericana cv. '74/76' plantation with ground drip irrigation. Forest Research 2013; 26: 766-772.

García-Arias A, Francés F, Morales-de la Cruz M, Real J, Vallés-Morán F, Garófano-Gómez V, et al. Riparian evapotranspiration modelling: Model description and implementation for predicting vegetation spatial distribution in semi-arid environments. Ecohydrology 2014; 7: 659-677.

Guidi W, Piccioni E, Bonari E. Evapotranspiration and crop coefficient of poplar and willow short-rotation coppice used as vegetation filter. Bioresource Technology 2008; 99: $4832-4840$

Hall D, Scrase J. Will Biomass Be the Environmentally Friendly Fuel of the Future ? Biomass and Bioenergy 2012; 15: 357-367. 
Hanson GC, Groffman PM, Gold AJ. Denitrification in riparian wetlands receiving high and low groundwater nitrate inputs. Journal of Environmental Quality 1994; 23: 917-922.

Hays KB. Water Use by Saltcedar (Tamarix Sp.) and Associated Vegetation on the Canadian, Colrado and Pecos Rivers in Texas. College Station. Texas A\&M University, TX, 2003, pp. 132.

Hu Y, Nan Z, Su J, Wang N. Heavy metal accumulation by poplar in calcareous soil with various degrees of multi-metal contamination: implications for phytoextraction and phytostabilization. Environmental Science and Pollution Research 2013; 20: 71947203.

Johansson T, Karačić A. Increment and biomass in hybrid poplar and some practical implications. Biomass and Bioenergy 2011; 35: 1925-1934.

Krause S, Bronstert A, Zehe E. Groundwater-surface water interactions in a North German lowland floodplain - Implications for the river discharge dynamics and riparian water balance. Journal of Hydrology 2007; 347: 404-417.

Langhoff JH, Rasmussen KR, Christensen S. Quantification and regionalization of groundwater-surface water interaction along an alluvial stream. Journal of Hydrology $2006 ; 320: 342-358$

Loheide SP, Butler JJ, Gorelick SM. Estimation of groundwater consumption by phreatophytes using diurnal water table fluctuations : A saturated-unsaturated flow assessment. Water Resources Research 2005; 41: 1-14.

Markovic T, Brkic Z, Larva O. Using hydrochemical data and modelling to enhance the knowledge of groundwater flow and quality in an alluvial aquifer of Zagreb, Croatia. Science of the Total Environment 2013; 458: 508-516.

Marmiroli M, Imperiale D, Maestri E, Marmiroli N. The response of Populus spp. to cadmium stress: Chemical, morphological and proteomics study. Chemosphere 2013; 93: 13331344

Mas-Pla J, Font E, Astui O, Mencio A, Rodriguez-Florit A, Folch A, et al. Development of a stream-aquifer numerical flow model to assess river water management under water 
scarcity in a Mediterranean basin. Science of the Total Environment 2012; 440: 204-

583

584

585

586

587

588

589

590

591

592

593

594

595

596

597

598

599

600

601

602

603

604

605

606

607

608 218.

McDonal MG, Harbaugh AW. A modular three-dimensional finite difference ground-water flow model. 83-875. USGS Open-file Report, Washington, 1988.

Medici C, Butturini A, Bernal S, Vazquez E, Sabater F, Velez JI, et al. Modelling the non-linear hydrological behaviour of a small Mediterranean forested catchment. Hydrological Processes 2008; 22: 3814-3828.

Meiresonne L, Nadezhdin N, Cermak J, Van Slycken J, Ceulemans R. Measured sap flow and simulated transpiration from a poplar stand in Flanders (Belgium). Agricultural and Forest Meteorology 1999; 96: 165-179.

Mencio A, Galan M, Boix D, Mas-Pla J. Analysis of stream-aquifer relationships: A comparison between mass balance and Darcy's law approaches. Journal of Hydrology 2014; 517 : $157-172$

Menció A, Folch A, Mas-Pla J. Analyzing hydrological sustainability through water balance. Environmental Management 2010; 45: 1175-1190.

Merseburger G, Marti E, Sabater F, Ortiz JD. Point-source effects on N and P uptake in a forested and an agricultural Mediterranean streams. Science of the Total Environment 2011; 409: 957-967.

Nowinski JD, Cardenas MB, Lightbody AF. Evolution of hydraulic conductivity in the floodplain of a meandering river due to hyporheic transport of fine materials. Geophysical Research Letters 2011; 38.

Pal JS, Giorgi F, Bi XQ. Consistency of recent European summer precipitation trends and extremes with future regional climate projections. Geophysical Research Letters 2004; 31.

Parkin G, Birkinshaw SJ, Younger PL, Rao Z, Kirk S. A numerical modelling and neural network approach to estimate the impact of groundwater abstractions on river flows. Journal of Hydrology 2007; 339: 15-28. 
Petzold R, Schwärzel K, Feger K-H. Transpiration of a hybrid poplar plantation in Saxony (Germany) in response to climate and soil conditions. European Journal of Forest Research 2010; 130: 695-706.

Pistocchi CaGWaPEaBE. Water requirements of poplar and willow vegetation filters grown in lysimeter under Mediterranean conditions : Results of the second rotation. Desalination 2009; 246: 137-146.

Puig R, Folch A, Menció A, Soler A, Mas-Pla J. Multi-isotopic study (15N, 34S, 18O, 13C) to identify processes affecting nitrate and sulfate in response to local and regional groundwater mixing in a large-scale flow system. Applied Geochemistry 2013; 32: 129141.

Quinn JJ, Negri MC, Hinchman RR, Moos LP, Wozniak JB, Gatliff EG. Predicting the effect of deep-rooted hybrid poplars on the groundwater flow system at a large-scale phytoremediation site. International Journal of Phytoremediation 2001; 3: 41-60.

Recchia L, Cini E, Corsi S. Multicriteria analysis to evaluate the energetic reuse of riparian vegetation. Applied Energy 2010; 87: 310-319.

Rees R, Robinson BH, Rog CJ, Papritz A, Schulin R. Boron accumulation and tolerance of hybrid poplars grown on a B-laden mixed paper mill waste landfill. Science of the Total Environment 2013; 447: 515-524.

Rosso L, Facciotto G, Bergante S, Vietto L, Nervo G. Selection and testing of Populus alba and Salix spp. as bioenergy feedstock: Preliminary results. Applied Energy 2013; 102: 8792.

Rowe RL, Street NR, Taylor G. Identifying potential environmental impacts of large-scale deployment of dedicated bioenergy crops in the UK. Renewable and Sustainable Energy Reviews 2009; 13: 271-290.

Sabater F, Bernal S. Keeping Healthy Riparian and Aquatic Ecosystems in the Mediterranean: Challenges and Solutions Through Riparian Forest Management. In: Boirot Y, Gracia C, Palahí M, editors. Water for Forests and People in the Mediterranean Region. 1, 2011, pp. 174. 
Sabater S, Butturini A, Clement JC, Burt T, Dowrick D, Hefting M, et al. Nitrogen removal by riparian buffers along a European climatic gradient: Patterns and factors of variation. Ecosystems 2003; 6: 20-30.

Sevigne E, Gasol CM, Brun F, Rovira L, Pagés JM, Camps F, et al. Water and energy consumption of Populus spp. bioenergy systems: A case study in Southern Europe. Renewable and Sustainable Energy Reviews 2011; 15: 1133-1140.

Shang TQ, Gordon MP. Transformation of C-14 trichloroethylene by poplar suspension cells. Chemosphere 2002; 47: 957-962.

Steinwand AL, Harrington RF. Water balance for Great Basin phreatophytes derived from eddy covariance, soil water, and water table measurements. Journal of Hydrology 2006; 329: $595-605$

Tabacchi E, Lambs L, Guilloy H, Planty-Tabacchi AM, Muller E, Decamps H. Impacts of riparian vegetation on hydrological processes. Hydrological Processes 2000; 14: 29592976.

Van Nevel L, Mertens J, De Schrijver A, Baeten L, De Neve S, Tack FMG, et al. Forest floor leachate fluxes under six different tree species on a metal contaminated site. Science of the Total Environment 2013; 447: 99-107.

White W. A method of estimating ground-water supplies based on discharge by plants and evaporation from soil. Results of investigation in Esscalante Valley, Utah. 1932: 1-110.

Wilske B, Lu N, Wei L, Chen S, Zha T, Liu C, et al. Poplar plantation has the potential to alter the water balance in semiarid Inner Mongolia. Journal of environmental management 2009; 90: 2762-70.

Yin L, Zhou Y, Ge S, Wen D, Zhang E, Dong J. Comparison and modification of methods for estimating evapotranspiration using diurnal groundwater level fluctuations in arid and semiarid regions. Journal of Hydrology 2013; 496: 9-16. 
Yin-Phan T, Hornberger G, Kaplan LA, Newbold JD, Aufdenkampe AK. A variable source area for groundwater evapotranspiration: impacts on modeling stream flow. Hydrological Processes 2014; 28: 2439-2450.

Zhang H, Morison JIL, Simmonds LP. Transpiration and water relations of poplar trees growing close to the water table. Tree physiology 1999; 19: 563-573.

668

669

670

\section{Figure captions}

672 Fig. 1. Aerial view indicating the main villages, the modelled area limits and the poplar 673 plantation locations.

674 Fig. 2. Geological map with groundwater contour lines for the shallow sedimentary aquifers

675 (Neogene and quaternary) of the Santa Coloma River basin (Field survey May 2009).

676 Fig. 3. Modelled domain with different parameters.

677 Fig. 4. Modelled domain with 20 hydraulic conductivity zones defined using outcrops, 678 boreholes and pumping tests data.

679 Fig. 5. Scheme of total evapotranspiration from poplars, where ETR $_{\mathrm{T}}$ is the total 680 evapotranspiration, ETRs is the evapotranspiration produced during water infiltration and 681 ETRgw is the groundwater directly evapotranspirated from the aquifer.

Fig. 6. Hydrogeomorphological changes in the main stream of the Santa Coloma over time.

Fig. 7. Observed versus simulated hydraulic head data in May 2009.

684 Fig. 8. Observed and simulated evolution of the hydraulic head as measured by a piezometer $685 \mathrm{ACA} / \mathrm{S}-11$ in the SCR alluvial aquifer. 
686 Fig. 9. Santa Coloma stream flow and total model output from the aquifer to the stream (total 687 output of drain + river boundary conditions).

688 Fig. 10. Trend in $\mathrm{hm}^{3} /$ month for River leakage in (contributions of the river to the aquifer) and 689 River leakage out (contributions of the aquifer to the river) during the study period.

690 Fig. 11. Stream flow loss and gain for the study period based on poplar plantations and 691 deciduous forests.

692 Fig. 12. Percentage change in the river base flow (River leakage in + out) with poplar 693 plantations compared with other land uses.

694 
1 Table 1. Obtained hydraulic conductivities for the entire model domain.

2

\begin{tabular}{ccc}
\hline Geological formations & Conductivity $(\mathrm{K})$ in $m /$ day & Specific storage $\left(\mathrm{S}_{\mathrm{s}}\right)$ in $\mathrm{m}^{-1}$ \\
\hline Alluvial formations (four zones) & Between 20 and 175 & 0.001 \\
Alluvial and Neogene & Around 0.25 & 0.002 \\
Granitic material (weathered) & 100 & 0.008 \\
Granitic material (non- & 0.20 & 0.03 \\
weathered) & 0.02 & 0.0001 \\
Volcanic formations & Between 0.03 and 0.10 & 0.001 \\
\hline
\end{tabular}

3 
1 Table 1. Mass balance results in $\mathrm{hm}^{3} /$ year for the transient simulation.

2

\begin{tabular}{cccccccccccc}
\hline Real & Modflow & & & & & & & \\
& & 2003 & 2004 & 2005 & 2006 & 2007 & 2008 & 2009 & 2010 & 2011 & Average \\
terminology & terminology & & & & & & & &
\end{tabular}

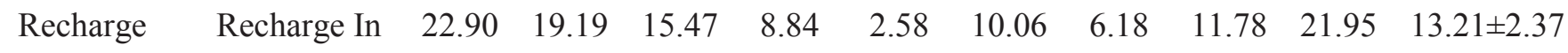

Contributions

through fault

GHB In

$\begin{array}{lll}1.43 & 1.43 \quad 1.43\end{array}$

$1.43 \quad 1.43$

$\begin{array}{lll}1.43 & 1.43 & 1.43\end{array}$

$1.43 \quad 1.43 \pm 0.00$

zones

Stream

River

losing Leakage In

$2.45 \quad 2.23$

2.45

$2.49 \quad 2.72$

2.69

2.65

$2.57 \quad 2.50$

$2.53 \pm 0.05$

Inflow from

upper

Constant flow

$0.12 \quad 0.11$

0.0

$0.06 \quad 0.00$

0.07

$0.05 \quad 0.07$

$0.14 \quad 0.07 \pm 0.01$

reaches

Returns from

waste water

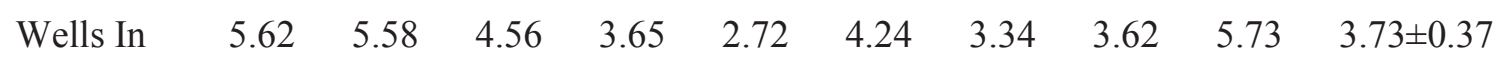

Total Inflow

Total inputs

32.52

$28.54 \quad 23.99$

$16.47 \quad 9.45$

18.49

$\begin{array}{llll}3.64 & 19.46 & 31.75 & 21.59 \pm 2.71\end{array}$

Stream

River

gaining Leakage Out

$\begin{array}{lll}4.60 & 5.59 & 4.29\end{array}$

$4.15 \quad 2.73$

$2.92 \quad 3.04$

3.39

4.97

$3.96 \pm 0.33$

Drains

Drains Out

10.16

$12.75 \quad 10.50$

$10.75 \quad 7.61$

7.60

$\begin{array}{llll}7.92 & 7.54 & 8.89 & 9.30 \pm 0.61\end{array}$

GW

extraction

$\begin{array}{lllllllllll}\text { Wells Out } & 3.88 & 3.47 & 3.93 & 4.37 & 4.32 & 3.81 & 5.02 & 4.07 & 4.01 & 4.10 \pm 0.15\end{array}$

GW

Poplar

Transpiration extraction

$\begin{array}{lllll}2.47 & 2.31 & 2.25 & 2.50 & 2.38\end{array}$

$2.38 \quad 2.52$

2.30

2.46

$2.40 \pm 0.03$

GW

discharge to

Constant

the next river

Head Out

$\begin{array}{lll}0.87 & 0.89 & 0.8\end{array}$

$0.82 \quad 0.78$

0.81

0.80

0.83

$0.87 \quad 0.83 \pm 0.01$ 
basin

\begin{tabular}{|c|c|c|c|c|c|c|c|c|c|c|c|}
\hline Total outflow & $\begin{array}{l}\text { Total } \\
\text { outputs }\end{array}$ & 21.98 & 25.00 & 21.82 & 22.58 & 17.82 & 17.52 & 19.29 & 18.12 & 21.20 & $20.59 \pm 0.85$ \\
\hline Storage & In-Out & 10.54 & 3.53 & 2.17 & -6.11 & -8.37 & 0.97 & -5.65 & 1.34 & 10.55 & $1.00 \pm 2.28$ \\
\hline
\end{tabular}


1 Table 3. Differences in the main terms of the simulated water budget using poplar plantations

2 compared with using deciduous forests. Negative values indicate a decrease in the contributions

3 and positive values indicate an increase in the inputs induced by plantations.

4

\begin{tabular}{|c|c|c|c|c|c|c|c|c|c|c|c|}
\hline $\begin{array}{c}\text { Real } \\
\text { terminology }\end{array}$ & $\begin{array}{l}\text { Modflow } \\
\text { terminology }\end{array}$ & 2003 & 2004 & 2005 & 2006 & 2007 & 2008 & 2009 & 2010 & 2011 & Average \\
\hline $\begin{array}{c}\mathrm{GW} \\
\text { Transpiration }\end{array}$ & $\begin{array}{c}\text { Poplar } \\
\text { extraction }\end{array}$ & 2.47 & 2.31 & 2.25 & 2.50 & 2.38 & 2.38 & 2.52 & 2.30 & 2.46 & 2.40 \\
\hline Stream loosing & $\begin{array}{c}\text { River } \\
\text { Leakage In }\end{array}$ & 0.06 & 0.07 & 0.07 & 0.08 & 0.08 & 0.09 & 0.09 & 0.08 & 0.09 & 0.08 \\
\hline Stream gaining & $\begin{array}{c}\text { River } \\
\text { Leakage } \\
\text { Out }\end{array}$ & -0.38 & -0.43 & -0.44 & -0.47 & -0.47 & -0.48 & -0.50 & -0.49 & -0.53 & -0.46 \\
\hline Drains & Drains Out & -0.59 & -1.00 & -1.13 & -1.25 & -1.25 & -1.31 & -1.37 & -1.41 & -1.47 & -1.20 \\
\hline $\begin{array}{l}\text { GW discharge } \\
\text { to the next } \\
\text { river basin }\end{array}$ & $\begin{array}{l}\text { Constant } \\
\text { Head Out }\end{array}$ & -0.04 & -0.05 & -0.05 & -0.05 & -0.05 & -0.05 & -0.05 & -0.05 & -0.05 & -0.05 \\
\hline Storage & In-Out & -1.39 & -0.76 & -0.57 & -0.79 & -0.57 & 0.20 & -1.19 & -0.29 & -0.35 & -0.63 \\
\hline
\end{tabular}


Figure 1

Click here to download high resolution image

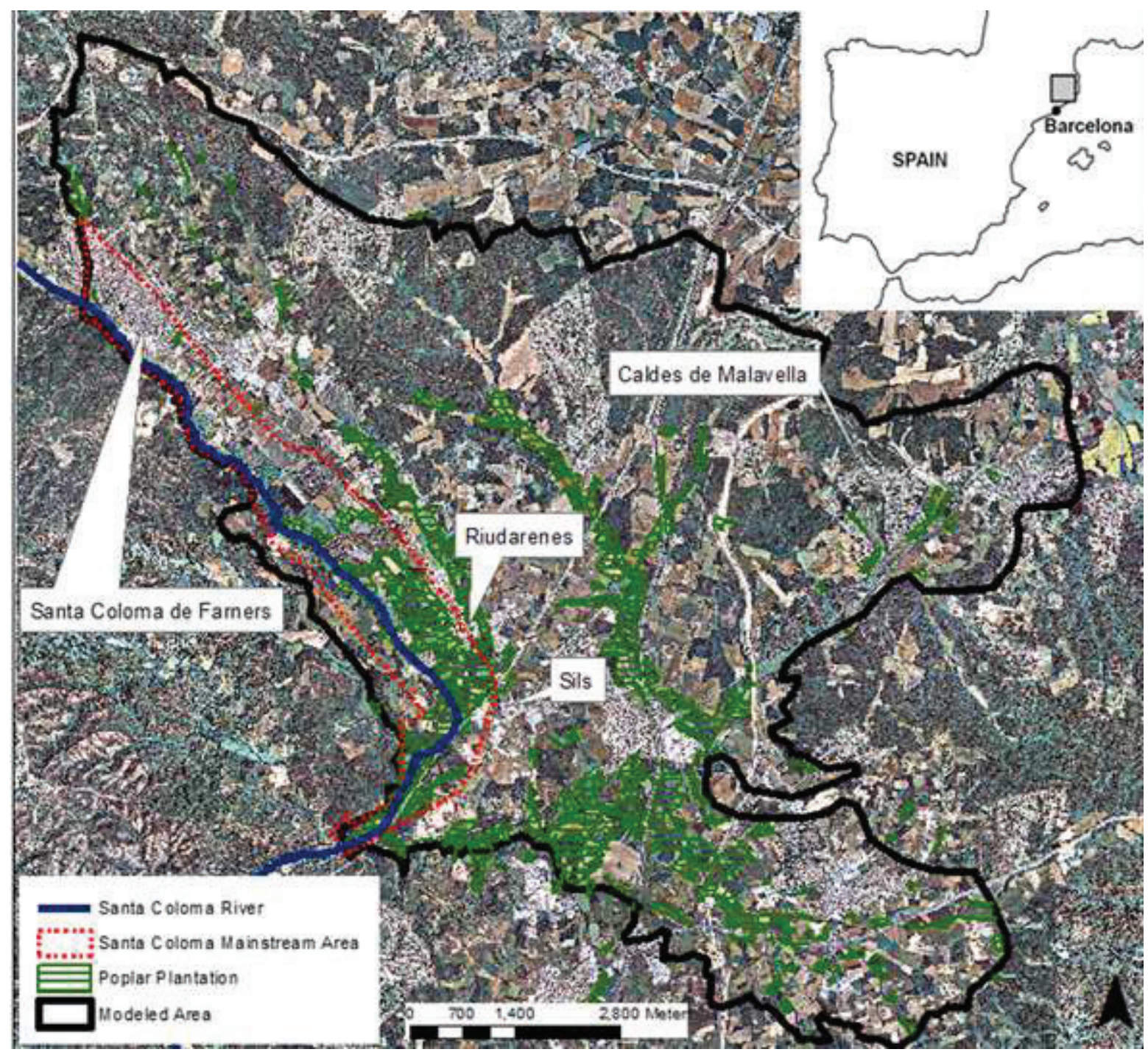




\begin{tabular}{|c|c|}
\hline & Santa Coloma River Basin \\
\hline & Moduled Area \\
\hline Geo & ogy \\
\hline Terti & \\
\hline & Neogene \\
\hline & Lubetian \\
\hline Quat & ernary \\
\hline & Roai chanel \\
\hline & Flivial serrace \\
\hline & Oid fuvial chanel abandoned \\
\hline & Aluvial deposits \\
\hline & Alluviai fan \\
\hline & Foothils moterials \\
\hline & Euvial deponts \\
\hline & Locustrine sediment \\
\hline & Travertine \\
\hline & Cariche crust \\
\hline & Pyroclats accumulation \\
\hline Pala & ozoic \\
\hline & Undifferentiated Paleoozoik \\
\hline $\lg n$ & us deposits \\
\hline & Neogene basalt \\
\hline & Ledges tom Corbeniferous.Permid \\
\hline & Lodges from Jurassic-Triasoic \\
\hline & Granodiontes and leucogranites \\
\hline & Orthogneiss: \\
\hline 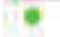 & Gauge sestion \\
\hline
\end{tabular}

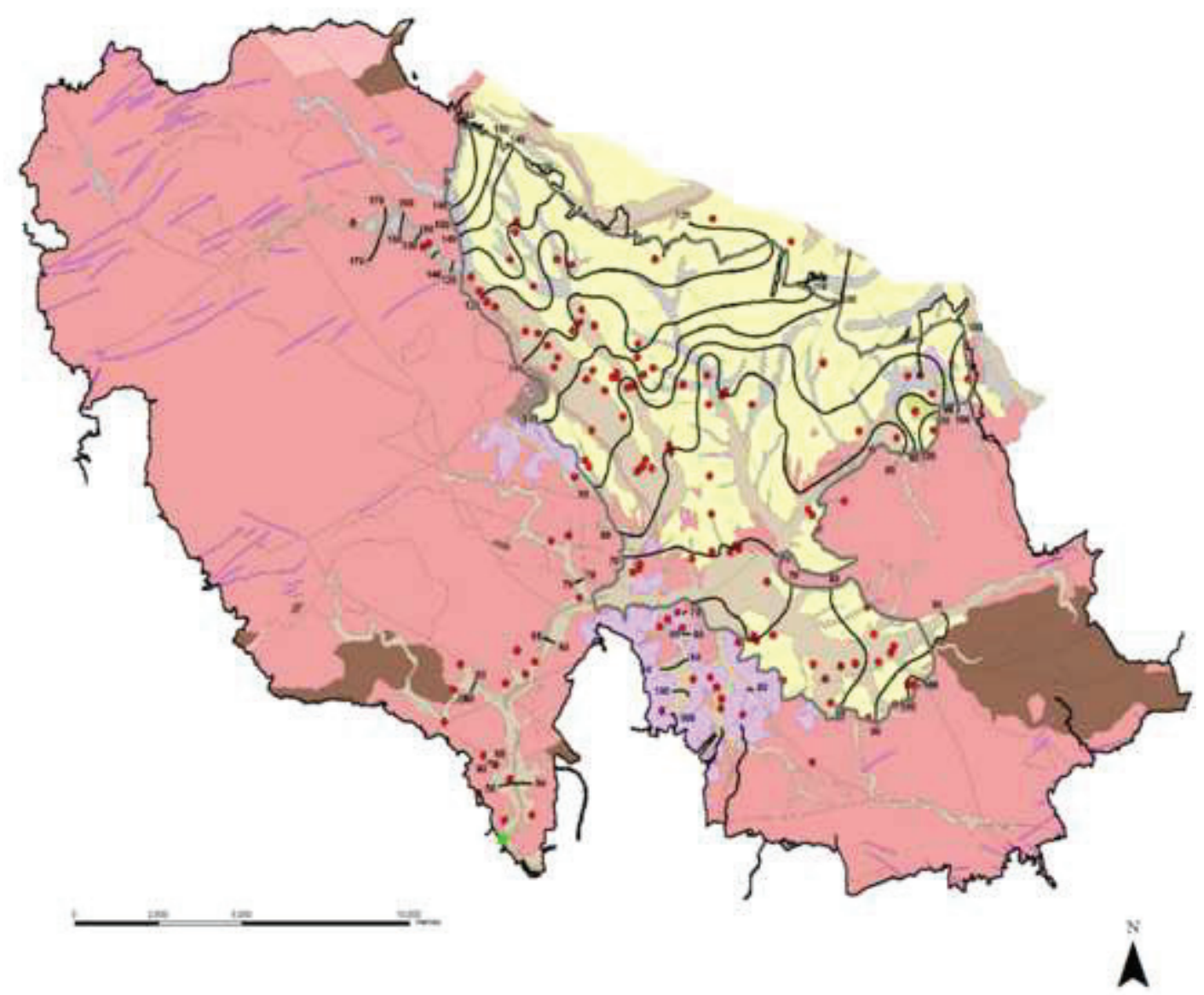




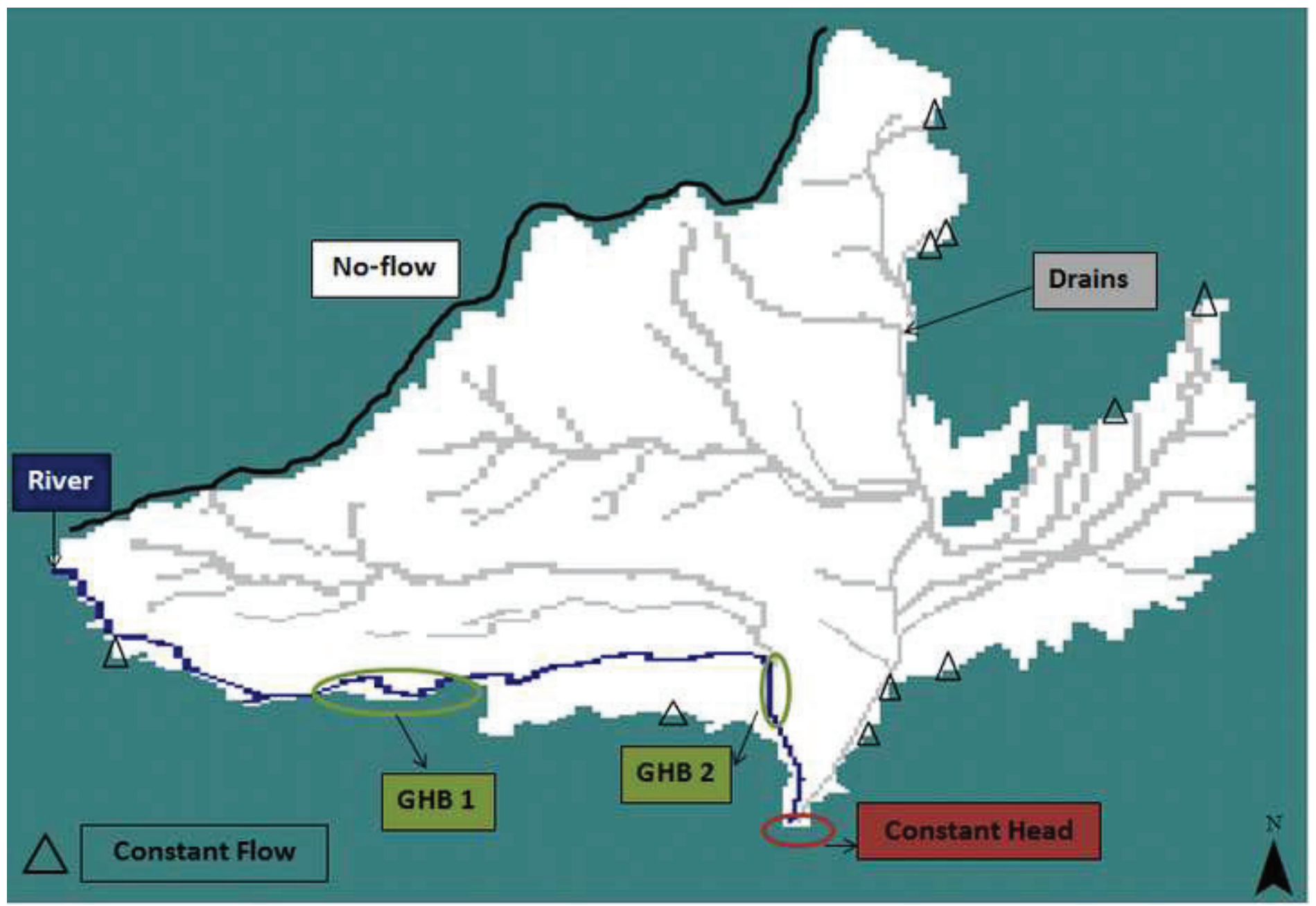




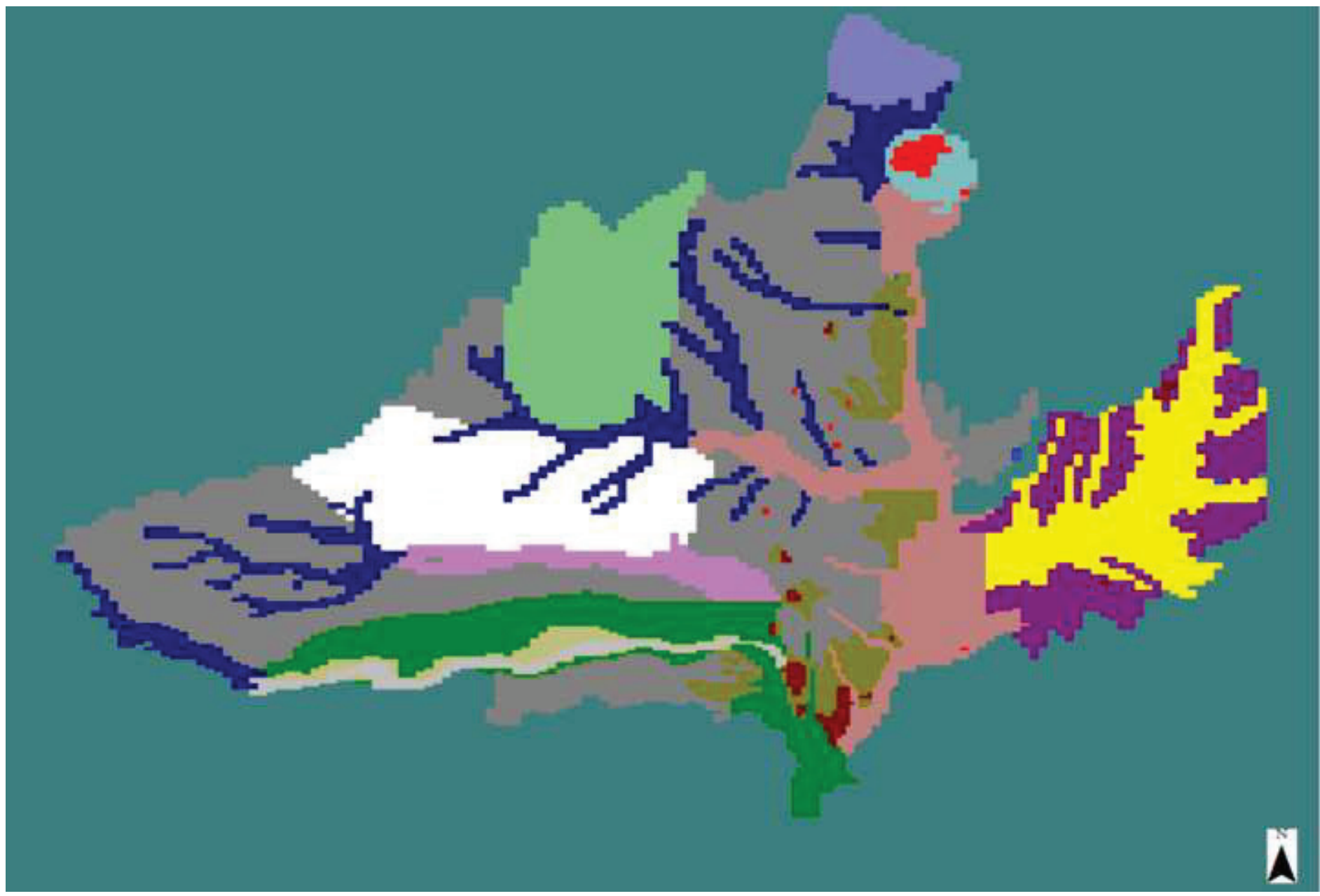


$E T R_{T}=E T R G W+E T R s$

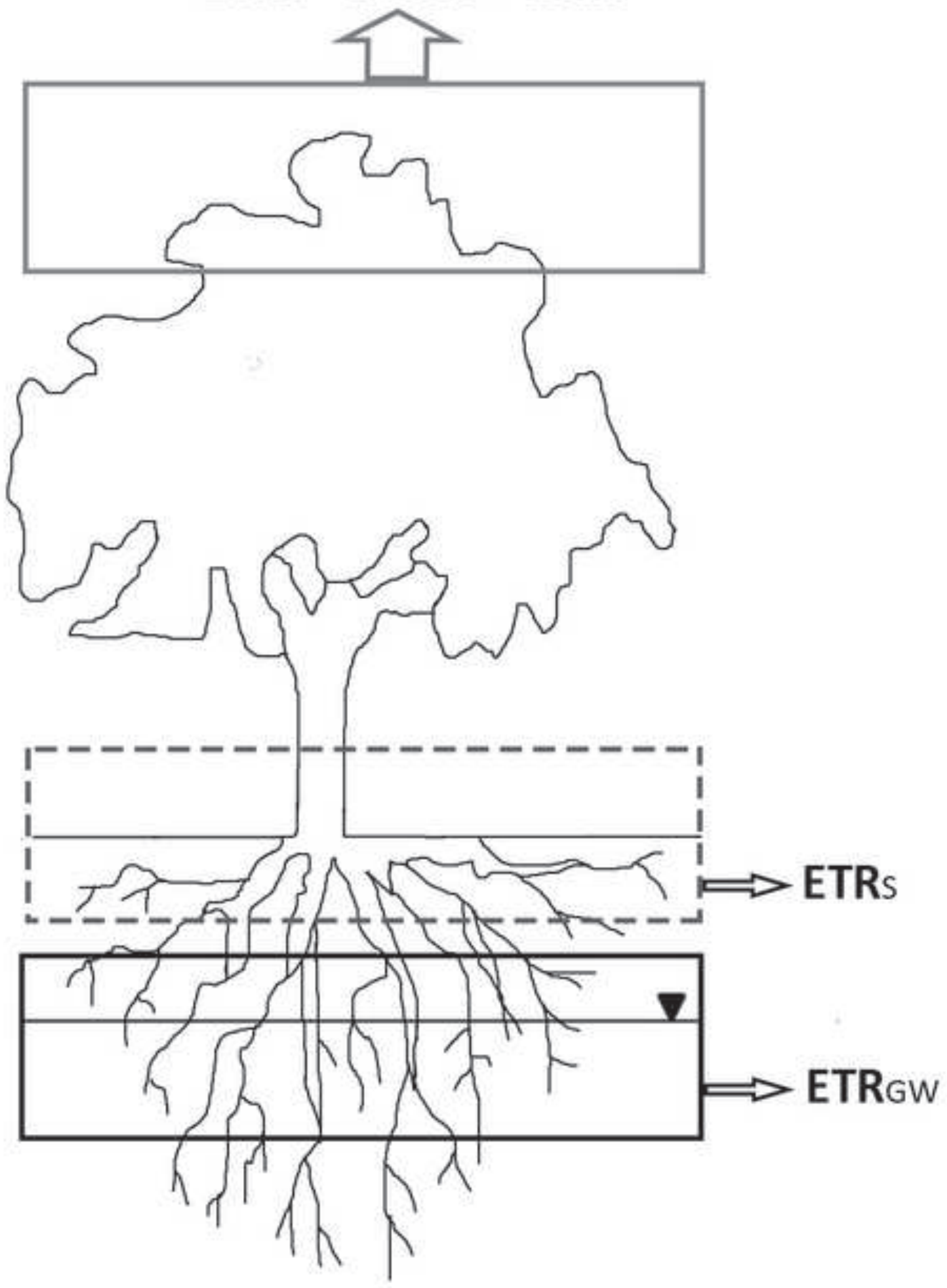




\section{Figure 6}

Click here to download high resolution image

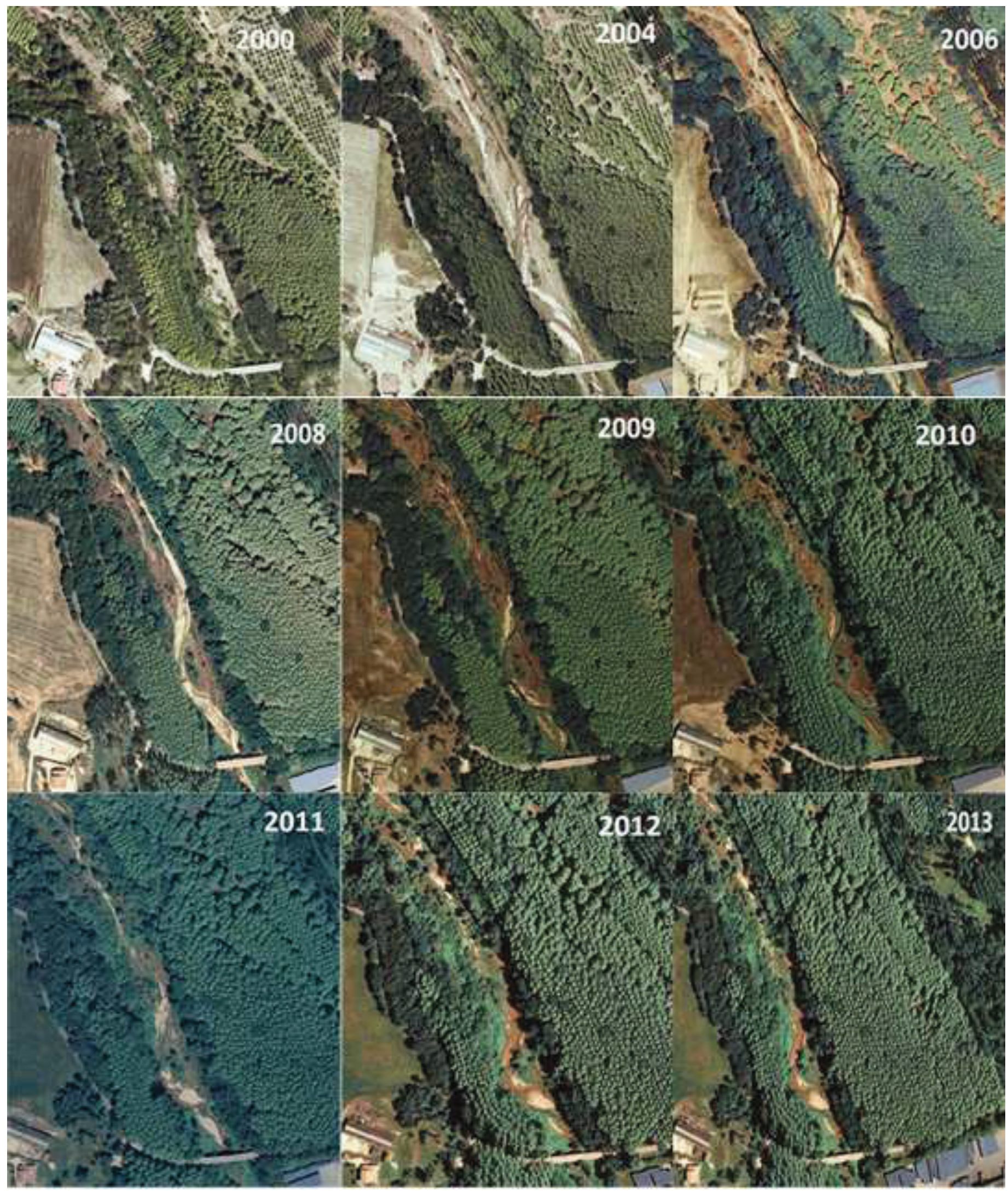




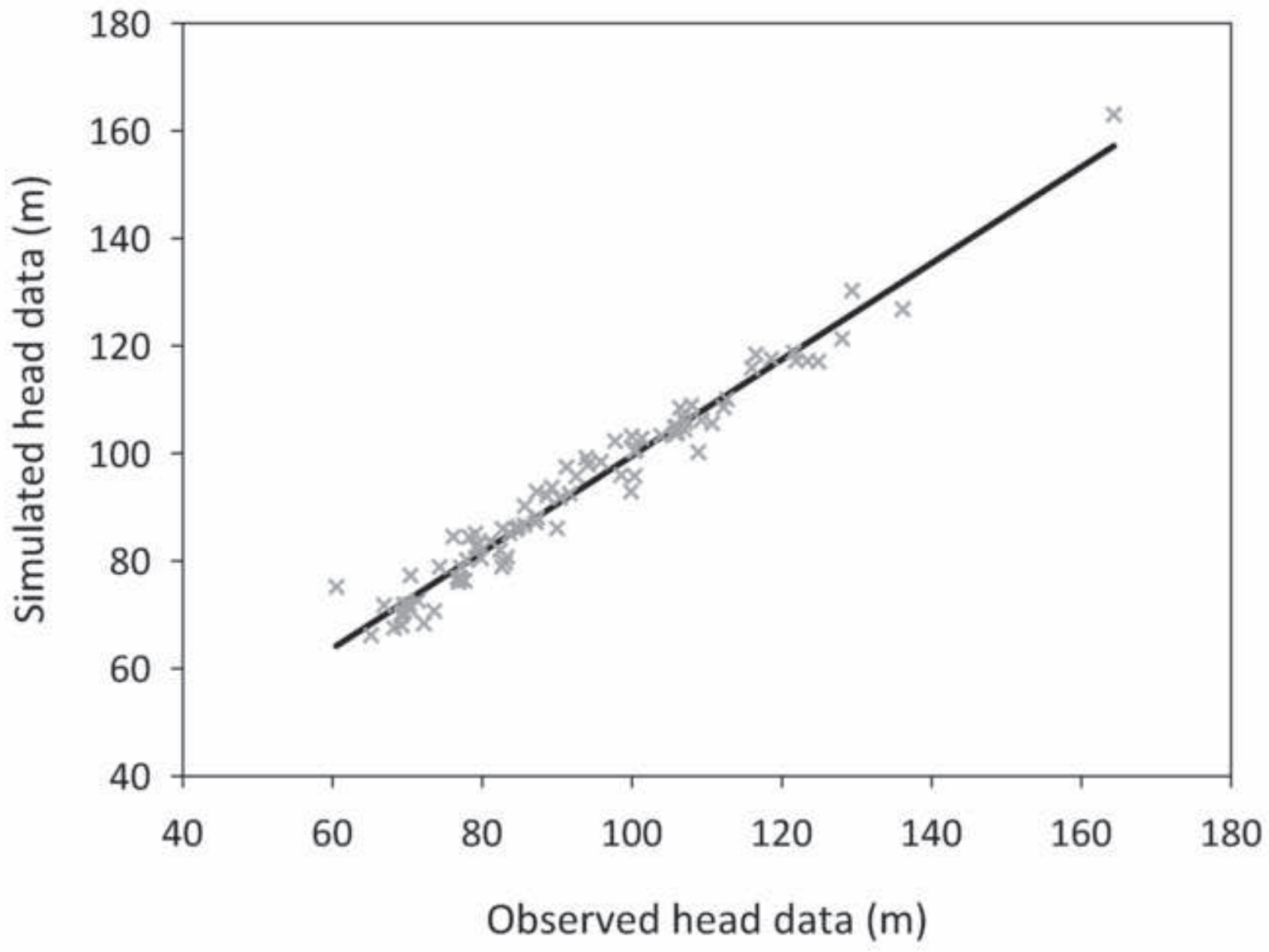




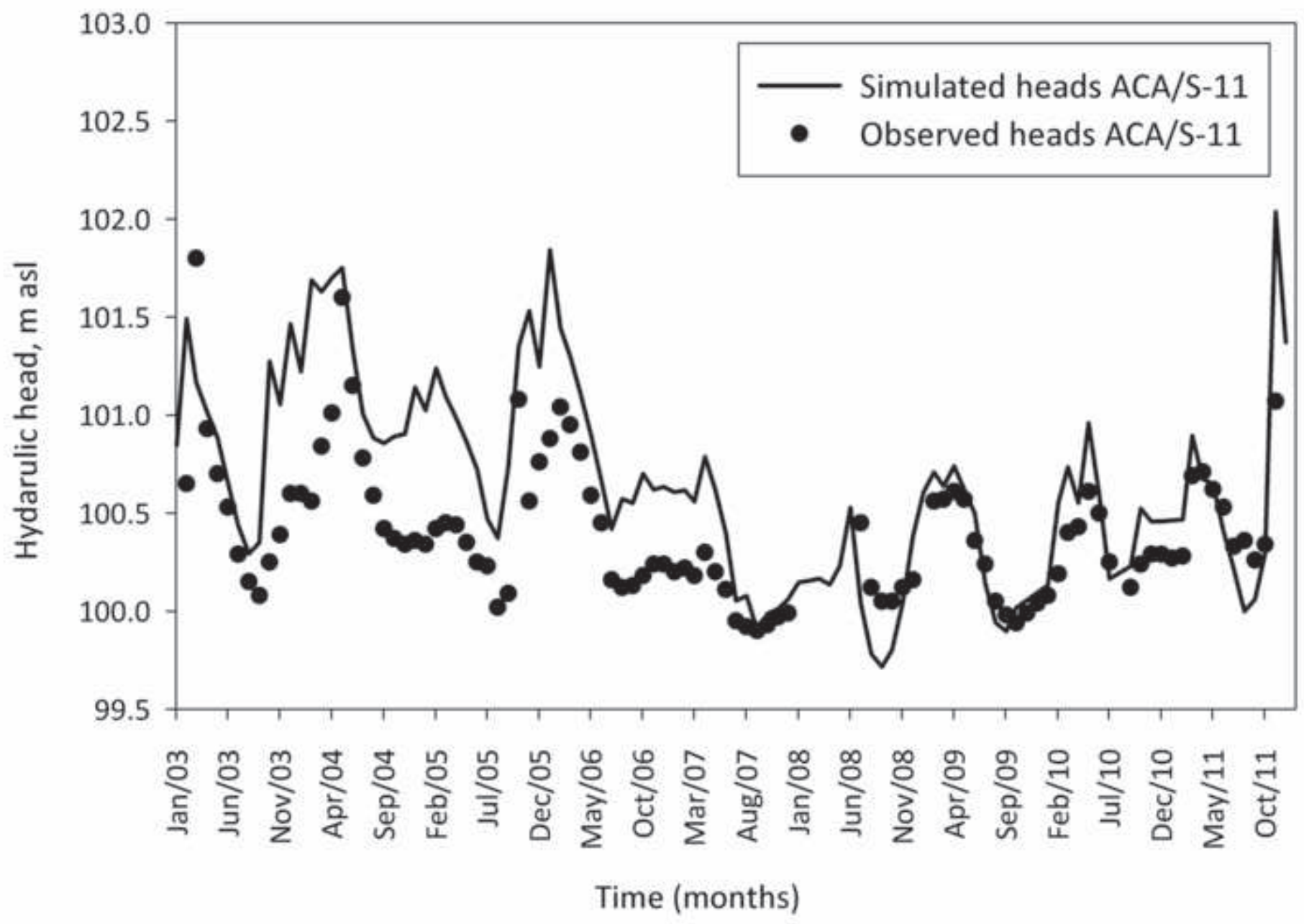




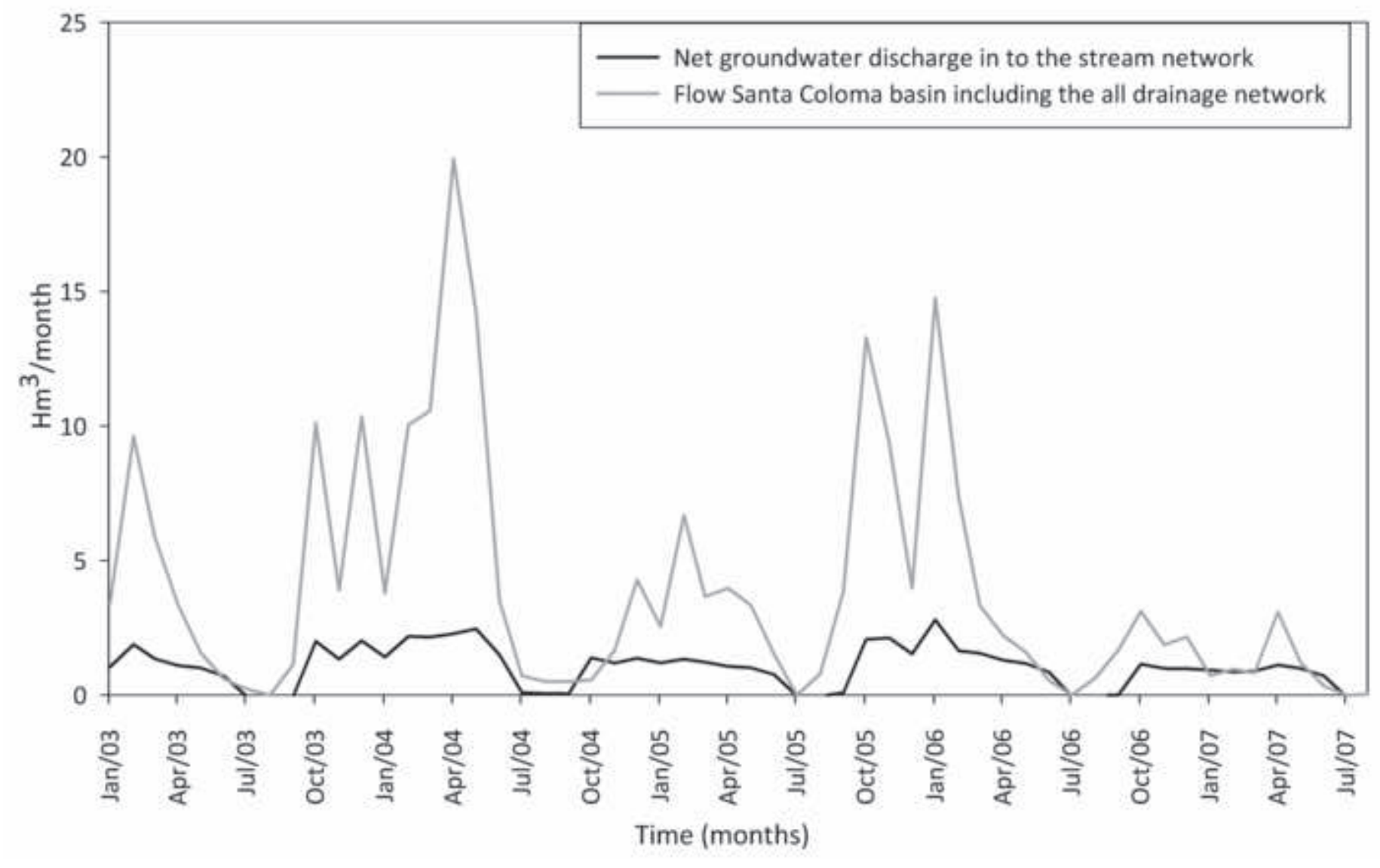




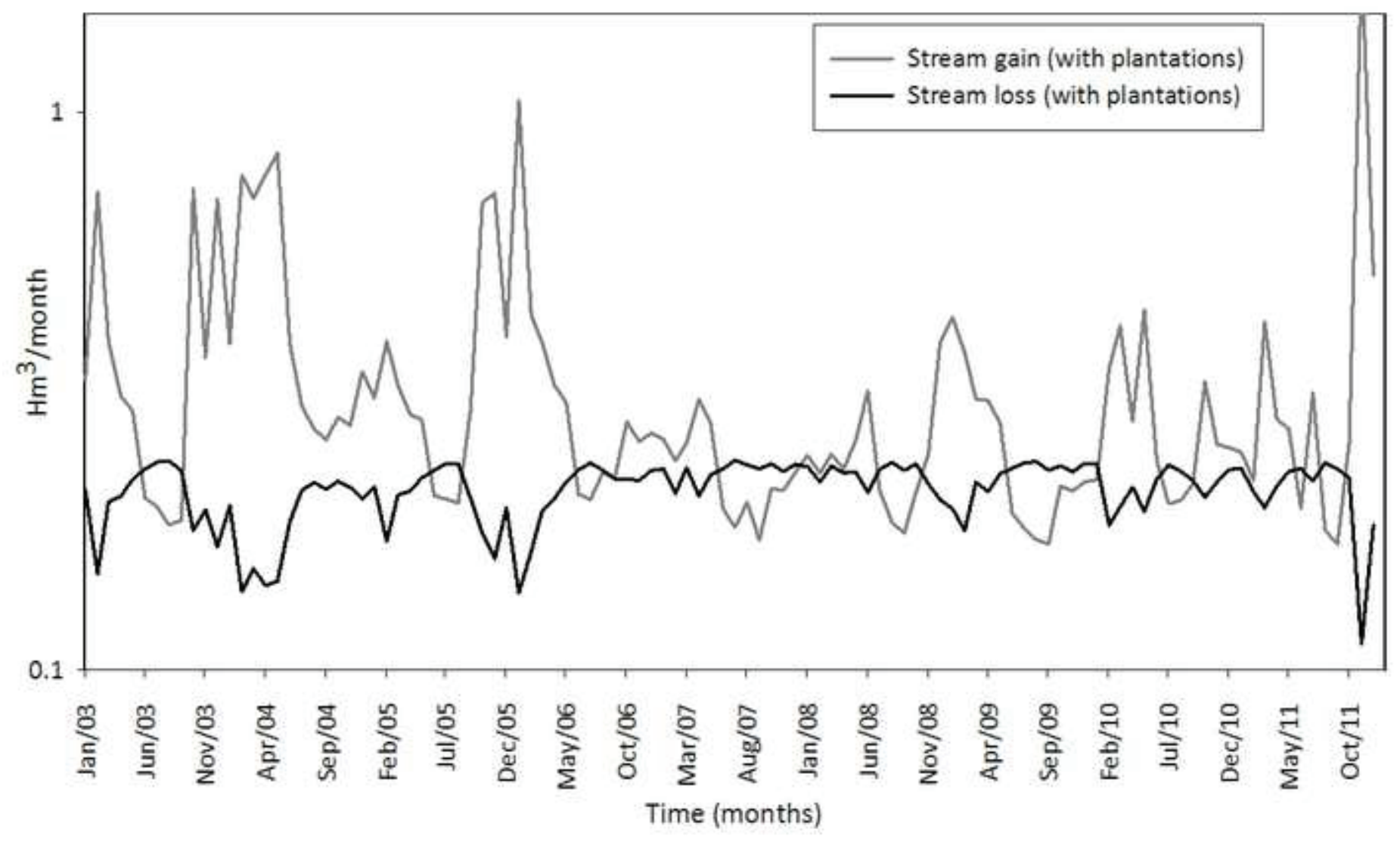




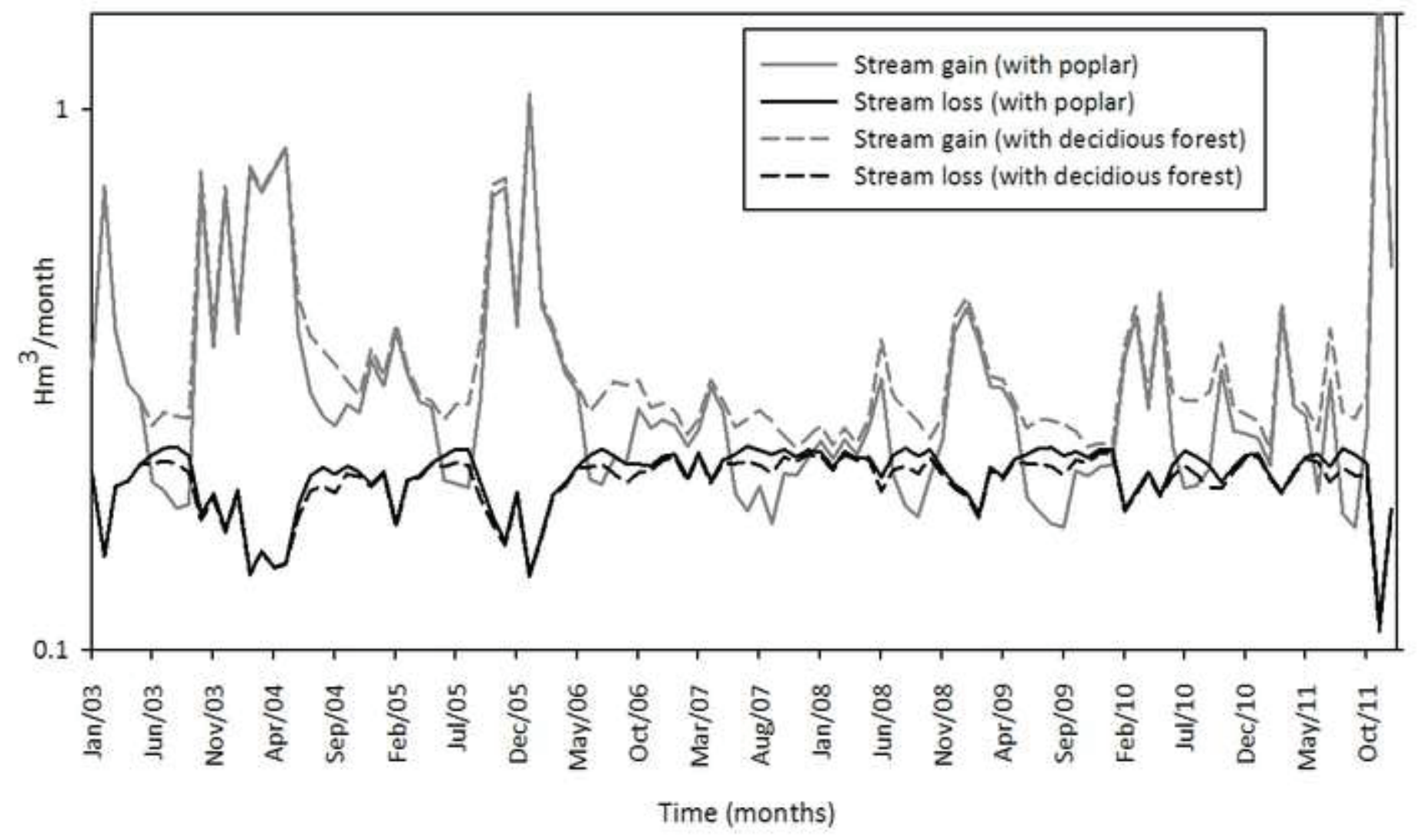




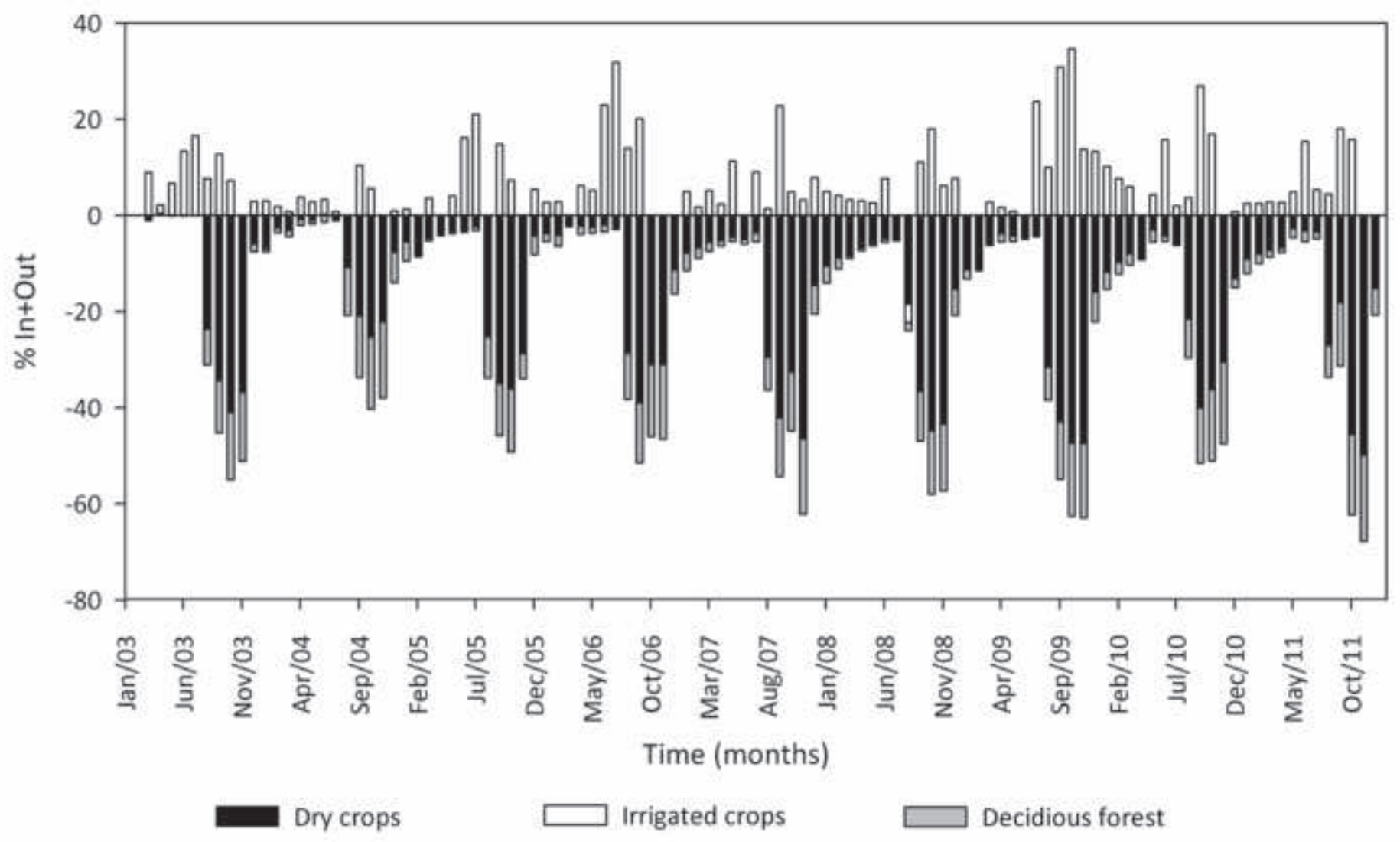

